\title{
BIOASSAY OF BIOORGANIC FERTILIZER OF PAPER MILL SLUDGE TO IMPROVE GROWTH AND NUTRIENT STATUS OF CORN
}

\author{
Happy Widiastuti *, Siswanto, Suharyanto \\ Indonesian Biotechnology Research Institute for Estate Crops \\ J1 Taman Kencana No 1 Bogor, 16151, Indonesia \\ * e-mail : happywidiastuti@yahoo.com
}

Diterima : 06 Maret 2012, Revisi akhir : 19 Juni 2012

\section{UJI PUPUK BIOORGANIK SLUDGE PABRIK KERTAS UNTUK MENINGKATKAN PERTUMBUHAN DAN STATUS HARA TANAMAN JAGUNG}

\begin{abstract}
ABSTRAK
Penelitian bertujuan menguji keefektifan pupuk bioorganik sludge (PBS) terhadap pertumbuhan, status hara tanaman dan kandungan logam biji jagung yang dihasilkan. Percobaan dilakukan untuk menguji tujuh perlakuan pupuk yaitu tanpa pupuk (A), pupuk anorganik 100\% (B), PBS granul formula $4+$ pupuk anorganik 50\% (C), PBS curah formula $4+$ pupuk anorganik 50\% (D), PBS granul formula $16+$ pupuk anorganik $50 \%$ (E), PBS curah formula $16+$ pupuk anorganik $50 \%$ (F), PBS curah formula $4+$ asam humat + pupuk anorganik $50 \%(\mathrm{G})$ yang disusun dalam rancangan lengkap acak kelompok dengan lima ulangan. Pupuk formula 4 mengandung Azotobacter sp. sedangkan formula 16 mengandung konsorsium bakteri pelarut fosfat, Azotobacter sp., dan Trichoderma sp. Penambahan PBS yang dikombinasi dengan pupuk anorganik 50\% menghasilkan pertumbuhan yang sama dengan jagung yang diberi pupuk anorganik 100\%. Pemberian PBS granul formula 4 menghasilkan status hara $\mathrm{N}$ dan $\mathrm{P}$ jaringan tanaman nyata lebih tinggi dibandingkan dengan yang dipupuk anorganik. Kandungan logam $\mathrm{Mo}, \mathrm{Co}, \mathrm{B}$ dan $\mathrm{Pb}$ lebih tinggi dalam biji jagung yang diberi PBS (G16) dibandingkan dengan yang dipupuk anorganik dan kontrol. Pemberian pupuk anorganik $100 \%$ menghasilkan biji jagung yang mengandung $\mathrm{Cu}, \mathrm{Zn}, \mathrm{Mn}$, dan Fe lebih tinggi daripada yang diberi PBS.
\end{abstract}

Kata kunci: pupuk bioorganik sludge, jagung, serapan hara, serapan logam

\section{ABSTRACT}

The study was aimed to test the effectiveness of organic sludge fertilizer on growth, nutrient status of plants and metal content of maize seed produced. Experiments was conducted to test 7 treatments namely without fertilizer (A), 100\% of inorganic fertilizer (B), fertilized with bioorganic granule fertilizer formula $4+50 \%$ inorganic fertilizer (C), fertilized with bulk bioorganic sludge fertilizer formula $4+50 \%$ inorganic fertilizer (D), fertilized with granule formula $16+50 \%$ inorganic fertilizer $(E)$, fertilized with bulk bioorganic formula $16+50 \%$ inorganic fertilizer $(F)$, fertilized with bulk bioorganic sludge fertilizer $4+$ humic acid $+50 \%$ inorganic fertilizer $(G)$ arranged in randomized completely block design with 5 replications. Bioorganic sludge fertilizer formula 4 contains Azotobacter sp. while formula 16 containing consortium of phosphate solubilizing bacteria + Azotobacter sp. + Trichoderma sp. Addition of bioorganic sludge fertilizer in combination with 50\% mineral fertilizer resulted similar growth of corn compared to those of 100\% mineral fertilizer. The addition of granule bioorganic sludge fertilizer formula 4 resulted significantly higher $N$ and $P$ nutrient status of corn plants both in terms of leaves, stems, roots, and seeds. Metal content of Mo, Co, B and Pb was higher in maize seed treated with bioorganic sludge fertilizer (G16) compared to mineral fertilizer. However, $100 \%$ mineral fertilizer yield maize seed containing $\mathrm{Cu}, \mathrm{Zn}, \mathrm{Mn}$, and Fe higher than those of fertilized with sludge bioorganic fertilizer.

Keywords: bioorganic sludge fertilizer, corn, nutrient uptake, metal uptake 


\section{INTRODUCTION}

Sludge is a waste which abundantly available compared with other type solid waste in paper industry. As other agro waste, paper mill sludge is an organic waste containing high amount of cellulose, hemicellulose, and lignin. Laboratory analysis indicates that the $\mathrm{C}$ compound of sludge was very high while the $\mathrm{N}$ content is very low that $\mathrm{C} / \mathrm{N}$ ratio is very high namely in ranged between 50 - 200 (Newspaper Industry Environmental Technology Initiative, 2000). Several studies have shown that both cellulose, hemicellulose, and lignin can be used as a source of $\mathrm{C}$ for lignocellulolytic organism. The activities of these organisms produce metabolically simple $\mathrm{C}$ compounds that is available to plant. The formation of simple $\mathrm{C}$ compounds and soluble nutrients make this material can be used as a raw material of bioorganic fertilizer.

Land degradation has reduced the productive capacity of soil on nearly $40 \%$ of the world's agricultural land (Oldeman, 1997). These soil suffer physical degradation (erotion and compaction), chemical degradation (acidification, nutrient depletion, pollution oberuse of pesticides and fertilizer) and biological degradation (organic matter depletion and loss biodiversity). The productivity of agricultural systems is known to depend greatly upon the functional processes of soil microbial communities (Girvan et al., 2003). The application of organic might be increase the health of microbial communities and conferring a positive effect upon soil biology. It enhanced biological activity due to reduced application of nutrients and elimination of pesticides.

Application of organic sludge fertilizer can reduce the use of inorganic fertilizer and improve soil organic matter content that generally very low $(<2.5 \%)$. Simard et al. (1998) showed that application of raw de-inking sludge (RDS) has a positive short-term on soil water, $\mathrm{P}, \mathrm{K}$ availability but reduces plant available soil $\mathrm{N}$ in the growing season after spring application. While sewage sludge compost has been widely used and utilization of this sewage sludge compost improve soil structure after the application for two years (Foley and Cooperband, 2002), increase crop production, and reduce disease attack (Vallad et. al., 2002). In addition, it is showed that the sludge compost application suppress disease attacks at the leaves of tomato and Arabidopsis plants (Vallad et al., 2003). Baziramakenga et al, (2001) showed that application of compost of de inking paper residues and poultry manure (DSPC) increased soil $\mathrm{pH}$ and water content, soil inorganic $\mathrm{N}$ just after application, $\mathrm{P}$ extractable, phosphatase and urease activities. Deinking sludge can be used as soil amendment when adequate $\mathrm{N}$ and $\mathrm{P}$ supplement are provided (Fierro et al., 1997). While Simard et al (1998) reported that raw de inking paper sludge (RDS) application has a positive short term effect on soil namely increase water, $\mathrm{P}$ and $\mathrm{K}$ availability but reduce plant available soil $\mathrm{N}$ in the growing season after spring application. The RDS may be used effectively as soil amendment if the crop receive adequate suplement of $\mathrm{N}$ mineral fertilizer. Results of other studies indicated that non-symbiotic nitrogen fixing bacteria increase $\mathrm{N}$ content on compost of bioorganic fertilizer that improve the effectiveness of organic fertilizer (Allahdadi et al., 2004).

Nutrient uptake is influenced by the availability of nutrients in the fertilizer formula. Nitrogen uptake of plant can be improved by preventing the occurrence of leaching by ground water in addition the $\mathrm{N}$ uptake of plant can be enhanced by inhibited the nitrification reaction. However, increasing soil $\mathrm{N}$ can also be done by adding non symbiotic $\mathrm{N}$ fixing microbe such as Azotobacter sp. In the case of $\mathrm{P}$, the constraint factor is the mobility and availability of $\mathrm{P}$ since the fixing ability of soil particle to $\mathrm{P}$ nutrient. However, uptake of both $\mathrm{N}$ and $\mathrm{P}$ influenced by the availability in the soil and the ability of plants to absorb. In addition, metal is also micro nutrient of plant that necessary in low amounts. The uptake of metal is influenced by the mobility, chemical form, and interaction with the environment (D'Amor et al., 2005). This study will test the effectiveness of two types of organic sludge fertilizer which is granule and bulk, and addition of two kind formula of microbes that are Azotobacter sp. and consortium of Azotobacter sp., phosphate solubilizing bacteria, and Trichoderma sp. in increasing the growth, and nutrient status of corn.

\section{MATERIALS AND METHODS}

Experiments were conducted in the Ciomas experimental station, Biotechnology Research Institute for Estate Crop Bogor, Indonesia. Bioorganic sludge fertilizer made from sludge of paper mills located in Bekasi. The paper industry 
use recycled paper as raw material without de inking process. Characteristics of metal contain in fertilizer sludge was presented in Table 1. The wide of experimental plots was $2 \times 1 \mathrm{~m}$, which contains 16 corn. The soil was previously clean from the grass and manage manually. Varieties of maize used was "Bhisma putih". The inorganic fertilizer standard (100\%) is urea, SP36, and $\mathrm{KCl}$ in dose of $7.5 \mathrm{~g}, 4.5 \mathrm{~g}$, and $4.5 \mathrm{~g}$ per plant respectively, while bioorganic sludge fertilizer dose is $50 \mathrm{~g}$ per plant. Humic acid derived from coal was added at rate of $0.8 \mathrm{ml}$ per plant $(\mathrm{C} 4-50 \mathrm{H})$.

The corn was harvested after 100 days. For biomass parameter, all of the biomass was harvested and weight while for tissue nutrient analyses, the samples were taken from $3^{\text {rd }}$ leave of three different plant each. Nutrient uptake was calculated as the nutrient concentration multiplied by dry weight each part of plant. Observations were made on plant height, leaf number, plant biomass and tissue nutrient content and selected metals concentration in the seed corn. The $\mathrm{N}$ and P nutrient content was analyzed using Kjedahl and spectrophotometer, respectively while $\mathrm{K}$ leaf and other metal content in seed were analyzed using AAS.

Treatments tested in this research were without fertilization (A), $100 \%$ of inorganic fertilizer (B), fertilized with bioorganic granule fertilizer formula $4+50 \%$ inorganic fertilizer (C), fertilized with bulk bioorganic sludge fertilizer formula $4+50 \%$ inorganic fertilizer (D), fertilized with granule formula $16+50 \%$ inorganic fertilizer (E), fertilized with bulk bioorganic formula $16+$ $50 \%$ inorganic fertilizer $(\mathrm{F})$, fertilized with bulk bioorganic sludge fertilizer $4+$ humic acid $+50 \%$ inorganic fertilizer $(G)$. Code of $G$ and $C$ refer to the form of bioorganic fertilizer i.e. granule and bulk respectively while code of 4 refer to the type of microbe as an biofertilizer active agent i.e. Azotobacter sp. while 16 containing three different microbe i.e. phosphate solubilizing bacteria, Azotobacter sp., and Trichoderma sp. Each treatment was repeated five times so that there are 35 units of the experiment.

\section{RESULTS AND DISCUSSIONS}

\section{Bioorganic Sludge Fertilizer}

The bioorganic sludge fertilizer tested in this study was granule and bulk. Bioorganic sludge fertilizer was made by previously composting of fresh sludge and mixed with bacteria. There are two different composition of bacteria as code 4 and 16. The bacteria in 4 formula is Azotobacter sp. while in formula 16 , is a consortium of phosphate solubilizing bacteria, Azotobacter sp., and Trichoderma sp. According to Widiastuti et al. (2007), the metal content fertilizer of sludge is $64,4.8,2.8,0.7,188,45.2,23.2,<0.01,<0.2 \mathrm{ppm}$ of $\mathrm{Cu}, \mathrm{Co}, \mathrm{Cr}, \mathrm{Cd}, \mathrm{Zn}, \mathrm{Mn}, \mathrm{Pb}$, Tin, B respectively while the total content of $\mathrm{Fe}$ is $0.55 \%$.

Table 1. Characteristic of Metal Contain in Bioorganic Fertilizer Sludge

\begin{tabular}{|c|c|c|c|}
\hline Metal analyzed & Methodes & Content & Oganic Fertilizer Standard (Ministry of Agriculture 2011) \\
\hline $\mathrm{Cu}$ & AAS (ppm) & 64.58 & $\max 5.000$ \\
\hline $\mathrm{Zn}$ & AAS (ppm) & 188.26 & $\max 5.000$ \\
\hline $\mathrm{Mn}$ & AAS (ppm) & 45.20 & $\max 5.000$ \\
\hline $\mathrm{Sn}$ & AAS (ppm) & $<0.01$ & - \\
\hline B & AAS (ppm) & $<2$ & - \\
\hline $\mathrm{Fe}$ & AAS $(\% \mathrm{~b} / \mathrm{b})$ & 0.55 & $\max 9.000$ \\
\hline $\mathrm{Pb}$ & AAS (ppm) & 23.2 & $\max 50$ \\
\hline $\mathrm{Cd}$ & AAS (ppm) & 0.7 & $\max 2$ \\
\hline Co & AAS (ppm) & 4.8 & $\max 700$ \\
\hline $\mathrm{Cr}$ & AAS (ppm) & 2.8 & $\max 210$ \\
\hline $\mathrm{Ni}$ & AAS (ppm) & 15.3 & $\max 62$ \\
\hline Mo & AAS (ppm) & 41.1 & $\max 20$ \\
\hline $\mathrm{Ag}$ & AAS (ppm) & 2.38 & - \\
\hline Sn & AAS (ppm) & $\mathrm{Td}$ & - \\
\hline $\mathrm{Se}$ & AAS (ppm) & 10.85 & $\max 2$ \\
\hline As & AAS (ppm) & td & $\max 10$ \\
\hline
\end{tabular}




\section{Vegetative Growth}

Application of bioorganic sludge fertilizer on corn showed that inorganic fertilizer is needed to enhance the growth of plant (Table 2). It seems there is no differences between the response of plants to inorganic fertilizer and bioorganic sludge fertilizer application. High growth rate of plants was shown in fertilized either inorganic or sludge bioorganic fertilizer seen after incubation for three months. Thus $50 \%$ of inorganic fertilizers can be replaced with bioorganic sludge fertilizer both in granule and bulk formula. These results indicate that the positive effect of organic fertilizer was shown on the growth of corn. In addition, the application of bioorganic sludge fertilizer reduced $50 \%$ the dosage of inorganic fertilizer or increased $50 \%$ inorganic fertilizer efficiency.

Table 2. Corn Height $(\mathrm{Cm})$ on Each Treatment

\begin{tabular}{|c|c|c|c|}
\hline Treatment & $\begin{array}{c}1^{\text {st }} \\
\text { month }\end{array}$ & $\begin{array}{c}2^{\text {nd }} \\
\text { month }\end{array}$ & $\begin{array}{c}3^{\text {rd }} \\
\text { month }\end{array}$ \\
\hline Unfertilizer & $56 b^{*}$ & $108 \mathrm{~b}$ & $135 \mathrm{~b}$ \\
\hline Mineral fertilizer & $81 \mathrm{ab}$ & $151 \mathrm{ab}$ & $179 \mathrm{a}$ \\
\hline $\mathrm{G} 4-50 * *$ & $99 \mathrm{a}$ & $167 \mathrm{a}$ & $185 \mathrm{a}$ \\
\hline $\mathrm{C} 4-50$ & $85 \mathrm{a}$ & $156 \mathrm{a}$ & $177 \mathrm{a}$ \\
\hline G16-50 & $82 \mathrm{ab}$ & $136 \mathrm{ab}$ & $168 \mathrm{a}$ \\
\hline C16-50 & $94 \mathrm{a}$ & $152 \mathrm{ab}$ & $176 \mathrm{a}$ \\
\hline C4-H50 & $94 \mathrm{a}$ & $139 a b$ & $178 \mathrm{a}$ \\
\hline \multicolumn{4}{|l|}{ Notes: } \\
\hline $\begin{array}{l}\text { * Figure in the sam } \\
\text { not significantly } \\
\text { ** G4-50: bioorgan } \\
\text { inorganic fertilize } \\
\text { sludgefertilizer fo } \\
\text { 50: fertilized with } \\
\text { fertilizer; C16-50 } \\
16+50 \% \text { inorg } \\
\text { bulk bioorganic s }\end{array}$ & $\begin{array}{l}\text { lumn follon } \\
\text { ent accordi } \\
\text { ranule fert } \\
\text { 4-50: fertil } \\
\text { la } 4+50 \% \\
\text { anule form } \\
\text { tilized with } \\
\text { fertilizer; } \\
\text { ge fertilizer }\end{array}$ & $\begin{array}{l}\text { d by same } \\
\text { g to DMR } \\
\text { zer formu } \\
\text { ed with bu } \\
\text { lorganicfe } \\
\text { a } 16+50 \\
\text { ulk bioorg } \\
4-H 50: f \\
4+\text { humi }\end{array}$ & $\begin{array}{l}\text { etter (s) are } \\
(P<0.05) \\
44+50 \% \\
\text { bioorganic } \\
\text { tilizer; G16- } \\
\text { o inorganic } \\
\text { nic formula } \\
\text { tilized with } \\
\text { acid }+50 \%\end{array}$ \\
\hline
\end{tabular}

The effect of treatment on the number of leaf did not differ with plant height especially one month incubation. It seems that the application of bioorganic sludge fertilizer was not affect the number of plant leaf compared to the application of inorganic fertilizer (Table 3).

Table 3. Number of Corn Leaf (Sheet) on Each Treatment

\begin{tabular}{lccc}
\hline \multicolumn{1}{c}{ Treatment } & $\begin{array}{c}1^{\text {st }} \\
\text { month }\end{array}$ & $\begin{array}{c}2^{\text {nd }} \\
\text { month }\end{array}$ & $\begin{array}{c}3^{\text {rd }} \\
\text { month }\end{array}$ \\
\hline Unfertilizer & $7.1 \mathrm{a}^{*}$ & $10.3 \mathrm{a}$ & $10.6 \mathrm{a}$ \\
Mineral fertilizer & $6.8 \mathrm{a}$ & $10.8 \mathrm{a}$ & $10.9 \mathrm{a}$ \\
G4-50 & $6.5 \mathrm{a}$ & $11.1 \mathrm{a}$ & $11.1 \mathrm{a}$ \\
C4-50 & $6.1 \mathrm{a}$ & $11.3 \mathrm{a}$ & $11.2 \mathrm{a}$ \\
G16-50 & $6.1 \mathrm{a}$ & $10.2 \mathrm{a}$ & $10.3 \mathrm{a}$ \\
C16-50 & $6.7 \mathrm{a}$ & $11.3 \mathrm{a}$ & $11.3 \mathrm{a}$ \\
C4-H50 & $6.7 \mathrm{a}$ & $9.7 \mathrm{a}$ & $9.7 \mathrm{a}$ \\
\hline
\end{tabular}

Notes:

* $\quad$ Figure in the same column followed by same letter (s) are not significantly different according to DMRT $(P<0.05)$

** G4-50: bioorganic granule fertilizer formula $4+50 \%$ inorganic fertilizer; C4-50: fertilized with bulk bioorganic sludge fertilizer formula $4+50 \%$ inorganic fertilizer; $G 16$ 50: fertilized with granule formula $16+50 \%$ inorganic fertilizer; C16-50: fertilized with bulk bioorganic formula $16+50 \%$ inorganic fertilizer; C4-H50: fertilized with bulk bioorganic sludge fertilizer $4+$ humic acid $+50 \%$ inorganic fertilizer

\section{The Weight of Fresh And Dry of Corn Biomass}

The fresh weight of corn biomass fertilized with bioorganic sludge fertilizer (G4-50, C4-50, and $\mathrm{C} 4-\mathrm{H} 50$ ) is similar to those of $100 \%$ inorganic fertilizer (Table 4). However, bioorganic sludge fertilizer treatment of formula G4-50 which is combined with $50 \%$ of inorganic fertilizers

Table 4. Corn Fresh Weight (g) Three Months After Treatment

\begin{tabular}{lcccc}
\hline \multicolumn{1}{r}{ Treatment } & Leaf & Stem & Root & Cob \\
\hline Unfertilizer & $35 \mathrm{~b}^{*}$ & $41 \mathrm{c}$ & $6.4 \mathrm{~b}$ & $79 \mathrm{c}$ \\
Mineral fertilizer & $69 \mathrm{a}$ & $77 \mathrm{ab}$ & $14.4 \mathrm{ab}$ & $138 \mathrm{~b}$ \\
G4-50** & $82 \mathrm{a}$ & $103 \mathrm{a}$ & $20.3 \mathrm{a}$ & $189 \mathrm{a}$ \\
C4-50 & $67 \mathrm{a}$ & $75 \mathrm{abc}$ & $14.1 \mathrm{ab}$ & $132 \mathrm{~b}$ \\
G16-50 & $52 \mathrm{ab}$ & $67 \mathrm{bc}$ & $12.3 \mathrm{ab}$ & $139 \mathrm{~b}$ \\
C16-50 & $62 \mathrm{ab}$ & $56 \mathrm{bc}$ & $14.7 \mathrm{ab}$ & $140 \mathrm{~b}$ \\
C4-H50 & $65 \mathrm{ab}$ & $71 \mathrm{abc}$ & $18.5 \mathrm{a}$ & $144 \mathrm{~b}$ \\
\hline
\end{tabular}

Notes:

* Figure in the same column followed by same letter (s) are not significantly different according to DMRT (P<0.05)

** G4-50: bioorganic granule fertilizer formula $4+50 \%$ inorganic fertilizer; C4-50: fertilized with bulk bioorganic sludge fertilizer formula $4+50 \%$ inorganic fertilizer; G16-50: fertilized with granule formula $16+50 \%$ inorganic fertilizer; C16-50: fertilized with bulk bioorganic formula $16+50 \%$ inorganic fertilizer; C4-H50: fertilized with bulk bioorganic sludge fertilizer $4+$ humic acid $+50 \%$ inorganic fertilizer 
produced significantly higher fresh weight of maize cob compared to $100 \%$ inorganic fertilizer.

It seem that Azotobacter sp. as an active agent of bioorganic sludge fertilizer formula 4 enhanced the $\mathrm{N}$ availability that resulted positive effect to the plant growth. Since N is the primary limiting factor to increase yield, the use of $\mathrm{N}$ fixing agents such as Azotobacter might be as alternative to increase corn production. The similar result has been reported by Simard et al. (1998).

Dry weight of corn showed a similar trend with fresh weight of plants (Table 5). These results indicate that application of bioorganic sludge fertilizer reduce at least $50 \%$ of the dose of inorganic fertilizer. Improvement of soil physical properties and the presence of several macro and micro nutrient content in bioorganic sludge fertilizer supposed to caused the improvement of plant growth. Since formula 4 (G4 and C4) containing Azotobacter sp. that fixed N atmosphere it seem likely that application of this bioorganic formula fertilizer improved the availability of $\mathrm{N}$ that reducing the dose of inorganic $\mathrm{N}$ fertilizer.

Differences of response of plant to fertilizer formula especially in the form of granules and bulk is probably due to possibilities of the higher leaching of nutrient contain in bulk formula compared to granule formula. This leads to higher plant growth of corn fertilized with granule formula compared to bulk formula. In addition, another possibility is the viability of microbes, especially Azotobacter sp. that is added in formula 4. Since the better air content in granule formula compared to bulk formula resulted better growth of this bacteria.

\section{N Uptake}

$\mathrm{N}$ uptake of corn plants are shown in Table 6. Application of $100 \%$ inorganic fertilizer increase $\mathrm{N}$ uptake, however bioorganic sludge fertilizer formula G4-50 which is accompanied with $50 \%$ dose of inorganic fertilization produced higher $\mathrm{N}$ uptake than those fertilized by $100 \%$ of inorganic fertilizer. The highest $\mathrm{N}$ uptake was observed in maize seed whereas the lowest $\mathrm{N}$ uptake was in corn roots. The high uptake of $\mathrm{N}$ in seeds is probably due to the function of seed as storage plant nutrients. Addition of G4-50 yield significantly higher total $\mathrm{N}$ corn uptake compared to addition of $100 \%$ mineral fertilizer. Bioorganic sludge fertilizer especially formula G4 may increase $\mathrm{N}$ cycling and reduce $\mathrm{N}$ losses compared with inorganic fertilizer. This type of fertilizer increase soil $\mathrm{N}$ storage and mineralization and reduce the potential for $\mathrm{N}$ loss compared with inorganic $\mathrm{N}$ fertilization, thereby reducing the need for $\mathrm{N}$. The higher $\mathrm{P}$ contain in inorganic fertilizer might be fixed by soil that not available to plant. This result showed that the higher dose of inorganic fertilizer seem not directly increase the nutrient uptake of plant.

P uptake of corn are presented in Table 7. The effect of treatment on plant $\mathrm{P}$ uptake had a similar pattern with $\mathrm{N}$ uptake. The plant was response to inorganic fertilizer as indicated by the increase in plant $\mathrm{P}$ uptake at $100 \%$ inorganic fertilizer treatment. Nevertheless bioorganic sludge fertilizer formula G4 reduce the dose of inorganic fertilizers by $50 \%$ and resulted in significantly a higher $\mathrm{P}$ uptake compared to $100 \%$ inorganic

Table 5. Dry Weight (g) of Corn in Each Treatment Three Months After Treatment

\begin{tabular}{lcccccc}
\hline \multicolumn{1}{c}{ Treatment } & Leaf & Stem & Root & Shoot & Cob & Total \\
\hline Unfertilizer & $7.66 \mathrm{~b}^{*}$ & $8.71 \mathrm{c}$ & $3.45 \mathrm{~b}$ & $19.82 \mathrm{c}$ & $17.58 \mathrm{~b}$ & $36.34 \mathrm{~b}$ \\
Mineral fertilizer & $16.72 \mathrm{a}$ & $18.15 \mathrm{ab}$ & $5.80 \mathrm{ab}$ & $40.66 \mathrm{ab}$ & $44.20 \mathrm{a}$ & $84.86 \mathrm{a}$ \\
G4-50** & $18.85 \mathrm{a}$ & $24.63 \mathrm{a}$ & $7.96 \mathrm{a}$ & $51.43 \mathrm{a}$ & $59.22 \mathrm{a}$ & $99.21 \mathrm{a}$ \\
C4-50 & $16.44 \mathrm{a}$ & $18.65 \mathrm{ab}$ & $6.69 \mathrm{ab}$ & $41.51 \mathrm{ab}$ & $42.11 \mathrm{a}$ & $83.62 \mathrm{a}$ \\
G16-50 & $13.13 \mathrm{ab}$ & $15.33 \mathrm{~b}$ & $5.57 \mathrm{ab}$ & $34.03 \mathrm{~b}$ & $41.31 \mathrm{a}$ & $75.33 \mathrm{a}$ \\
C16-50 & $15.74 \mathrm{a}$ & $17.26 \mathrm{~b}$ & $6.56 \mathrm{ab}$ & $38.58 \mathrm{ab}$ & $45.65 \mathrm{a}$ & $84.22 \mathrm{a}$ \\
C4-H50 & $15.17 \mathrm{a}$ & $18.67 \mathrm{a}$ & $7.19 \mathrm{a}$ & $39.24 \mathrm{ab}$ & $39.27 \mathrm{a}$ & $78.51 \mathrm{a}$ \\
\hline
\end{tabular}

Notes:

* Figure in the same column followed by same letter (s) are not significantly different according to DMRT $(P<0.05)$

** G4-50: bioorganic granule fertilizer formula $4+50 \%$ inorganic fertilizer; C4-50: fertilized with bulk bioorganic sludge fertilizer formula $4+50 \%$ inorganic fertilizer; G16-50: fertilized with granule formula $16+50 \%$ inorganic fertilizer; C16-50: fertilized with bulk bioorganic formula $16+50 \%$ inorganic fertilizer; C4-H50: fertilized with bulk bioorganic sludge fertilizer $4+$ humic acid $+50 \%$ inorganic fertilizer 
Table 6. N uptake of The Corn (g/Plant) in Each Treatment

\begin{tabular}{lccccc}
\hline \multicolumn{1}{c}{ Treatment } & Leaf & Stem & Root & Seed & Total \\
\hline Unfertilizer & $12.90 \mathrm{~d}^{*}$ & $6.24 \mathrm{~d}$ & $3.01 \mathrm{~d}$ & $28.19 \mathrm{c}$ & $48.00 \mathrm{c}$ \\
Mineral fertilizer & $27.81 \mathrm{ab}$ & $15.79 \mathrm{~b}$ & $5.34 \mathrm{bc}$ & $66.60 \mathrm{~b}$ & $107.27 \mathrm{~b}$ \\
G4-50** & $31.98 \mathrm{a}$ & $19.13 \mathrm{a}$ & $7.69 \mathrm{a}$ & $94.37 \mathrm{a}$ & $145.81 \mathrm{a}$ \\
C4-50 & $24.72 \mathrm{bc}$ & $13.80 \mathrm{~b}$ & $6.49 \mathrm{ab}$ & $72.57 \mathrm{~b}$ & $114.35 \mathrm{~b}$ \\
G16-50 & $21.31 \mathrm{c}$ & $11.34 \mathrm{c}$ & $4.33 \mathrm{c}$ & $66.23 \mathrm{~b}$ & $108.26 \mathrm{~b}$ \\
C16-50 & $21.72 \mathrm{c}$ & $13.98 \mathrm{~b}$ & $5.27 \mathrm{bc}$ & $73.19 \mathrm{~b}$ & $112.75 \mathrm{~b}$ \\
C4-H50 & $22.84 \mathrm{bc}$ & $15.43 \mathrm{~b}$ & $7.33 \mathrm{a}$ & $62.05 \mathrm{~b}$ & $103.07 \mathrm{~b}$ \\
\hline
\end{tabular}

Notes:

* Figure in the same column followed by same letter (s) are not significantly different according to DMRT $(P<0.05)$

** G4-50: bioorganic granule fertilizer formula $4+50 \%$ inorganic fertilizer; C4-50: fertilized with bulk bioorganic sludge fertilizer formula $4+50 \%$ inorganic fertilizer; G16-50: fertilized with granule formula $16+50 \%$ inorganic fertilizer; C16-50: fertilized with bulk bioorganic formula $16+50 \%$ inorganic fertilizer; C4-H50: fertilized with bulk bioorganic sludge fertilizer $4+$ humic acid $+50 \%$ inorganic fertilizer

Table 7. P uptake of Corn Crop (g/Plant) in Each Treatment

\begin{tabular}{lccccc}
\hline \multicolumn{1}{c}{ Treatment } & Leaf & Stem & Root & Seed & Total \\
\hline Unfertilizer & $1.30 \mathrm{c}^{*}$ & $0.81 \mathrm{~d}$ & $0.74 \mathrm{~d}$ & $5.80 \mathrm{c}$ & $8.65 \mathrm{c}$ \\
Mineral fertilizer & $3.07 \mathrm{ab}$ & $1.88 \mathrm{~b}$ & $1.47 \mathrm{~b}$ & $13.41 \mathrm{~b}$ & $19.82 \mathrm{~b}$ \\
G4-50** & $3.71 \mathrm{a}$ & $2.55 \mathrm{a}$ & $1.91 \mathrm{a}$ & $18.52 \mathrm{a}$ & $26.68 \mathrm{a}$ \\
C4-50 & $2.41 \mathrm{~b}$ & $1.74 \mathrm{bc}$ & $1.47 \mathrm{~b}$ & $13.48 \mathrm{~b}$ & $19.10 \mathrm{~b}$ \\
G16-50 & $2.32 \mathrm{~b}$ & $1.48 \mathrm{c}$ & $1.15 \mathrm{c}$ & $13.22 \mathrm{~b}$ & $18.17 \mathrm{~b}$ \\
C16-50 & $2.41 \mathrm{ab}$ & $1.73 \mathrm{bc}$ & $1.68 \mathrm{ab}$ & $14.30 \mathrm{~b}$ & $20.13 \mathrm{~b}$ \\
$\mathrm{C} 4-H 50$ & $3.08 \mathrm{ab}$ & $1.87 \mathrm{~b}$ & $1.68 \mathrm{ab}$ & $12.04 \mathrm{~b}$ & $18.67 \mathrm{~b}$ \\
\hline
\end{tabular}

Notes:

* Figure in the same column followed by same letter (s) are not significantly different according to DMRT $(P<0.05)$

** G4-50: bioorganic granule fertilizer formula $4+50 \%$ inorganic fertilizer; C4-50: fertilized with bulk bioorganic sludge fertilizer formula $4+50 \%$ inorganic fertilizer; G16-50: fertilized with granule formula $16+50 \%$ inorganic fertilizer; C16-50: fertilized with bulk bioorganic formula $16+50 \%$ inorganic fertilizer; C4-H50: fertilized with bulk bioorganic sludge fertilizer $4+$ humic acid $+50 \%$ inorganic fertilizer

fertilizer treatment. It seems that organic matter in bioorganic fertilizer could reduce the soil fixing of $\mathrm{P}$ that increase the avaibility of $\mathrm{P}$ to plant.

Similarly, the N nutrient, the P uptake in seed of corn was the highest. Uptake of $\mathrm{N}$ and $\mathrm{P}$ in the granules is higher than bulk particularly in formula 4 . This is probably caused by nutrient contained in the granules do not easily leaching as resulted from ground water that nutrients can be absorbed by plants much higher compared to the bulk. In addition, it appears that in the granule formula microbial viability as active agents of biological fertilizer in the bioorganic fertilizer was higher compared to the bulk formula.

Metal is a necessary as cofactor of several enzymes of plant metabolisms. Unfortunately this high metal content in food becomes limiting for food security. The results showed that the metal content of $\mathrm{Mo}, \mathrm{Co}, \mathrm{B}$, and $\mathrm{Pb}$ of maize seed fertilized with granule bioorganic sludge fertilizer of G16 formula is higher than that of fertilized with $100 \%$ inorganic fertilizer (Table 8). In addition, similar result with $\mathrm{N}$ and $\mathrm{P}$ nutrient content of seed, application of granule fertilizer resulted metal uptake of plant higher than those of bulk formula. However, 100\% inorganic fertilized corn seed also contain $\mathrm{Cu}, \mathrm{Zn}, \mathrm{Mn}$, and Fe higher compared to corn seed that is fertilized with bioorganic sludge fertilizer. The higher uptake of metal supposed to be resulted from the ink content of recycled paper used as raw material of this paper industry. However, there is no enough data weather this metal content of corn seed derived from sludge, soil or inorganic fertilizer. Since standarization of metal content in corn seed as food has not been determined, we do not know weather the corn seed is safe for food. However, the research should be continued to reduce the metal content of sludge as raw material of bioorganic fertilizer. 
Tabel 8. The Content of Selected Metals (ppm) in Seed Maize

\begin{tabular}{lccccccccccc}
\hline Treatment & $\mathrm{Mo}$ & $\mathrm{Co}$ & $\mathrm{As}$ & $\mathrm{Hg}$ & $\mathrm{Cu}$ & $\mathrm{Zn}$ & $\mathrm{Mn}$ & $\mathrm{Fe}$ & $\mathrm{Pb}$ & $\mathrm{Cd}$ & $\mathrm{B}$ \\
\hline Unfertilizer & 0.29 & 0.03 & 0 & 0 & 2.2 & 34.8 & 3.9 & 225 & 0 & 0 & 398 \\
Min. fert. & 0.59 & 0.07 & 0 & 0 & 3.7 & 31.7 & 5.2 & 282 & 0 & 0 & 1.2 \\
G4-50* & 1.47 & 0.12 & 0 & 0 & 1.7 & 27.2 & 4.2 & 180 & 18.4 & 0 & 2.3 \\
C4-50 & 0.59 & 0.05 & 0 & 0 & 1.7 & 25.0 & 3.6 & 197 & 0 & 0 & 958 \\
G16-50 & 4.41 & 14.3 & 4.4 & 0 & 1.4 & 25.2 & 0.6 & 215 & 26.3 & 0 & 2 \\
C16-50 & 0.29 & 0.03 & 0 & 0 & 1.3 & 29.6 & 0.9 & 251 & 0 & 0 & 2 \\
C4-H50 & 0.59 & 0.05 & 0 & 0 & 2.4 & 26.6 & 1.4 & 177 & 29.7 & 0 & 3 \\
\hline
\end{tabular}

Note :

* G4-50: bioorganic granule fertilizer formula $4+50 \%$ inorganic fertilizer; $C 4-50$ : fertilized with bulk bioorganic sludge fertilizer formula $4+50 \%$ inorganic fertilizer; G16-50: fertilized with granule formula $16+50 \%$ inorganic fertilizer; C16-50: fertilized with bulk bioorganic formula $16+50 \%$ inorganic fertilizer; C4-H50: fertilized with bulk bioorganic sludge fertilizer $4+$ humic acid $+50 \%$ inorganic fertilizer

\section{Conclusion and Suggestion}

Bioorganic sludge fertilizer granule formula 4 (G4 or C4) and formula 16 (G16 or C16) can be used to enhance growth and biomass of maize plants and reduce the dose of inorganic fertilizers by $50 \%$. N and $\mathrm{P}$ uptake increased with the application of bioorganic sludge fertilizer. Unfortunately, the uptake of heavy metals on seed maize occurs in both the application of inorganic fertilizers and bioorganic sludge fertilizer. Metal content, especially $\mathrm{Mo}, \mathrm{Co}, \mathrm{B}$ and $\mathrm{Pb}$ was higher in the maize seed treated with sludge bioorganic fertilizer (G4) compared to those of inorganic fertilized. Research needs to be continued to reduce metal uptake of plant especially in food crops.

\section{References}

Allahdadi, I., C. J. Beauchamp, and F. Chalifour., 2004, Symbiotic dinitrogen fixation in forage legumes amended with high rates of de-inking paper sludge, Agron J: 96: 956-965.

Baziramakenga, R., R. R. Lalande, R. Lalande., 1998, Effect od de-inking paper sludge compost application on soil chemical and biological properties, Can J Soil Scie 81(5), 561-575.

D'Amor, J J., S R Al Abed, K G Scheckel and J A Ryan., 2005, Methods for speciation of metals in soils : A review, J Environ Qual. 34, 17071745.
Fierro, A. J. Norre, A. Gosseli, C. J. Beauchamp. 1997, Deinking sludge influences biomass, nitrogen, and phosphorus status of several grass and legume species, Can J Soil Scie. 77, 693-702.

Foley, B.J. and L. R. Cooperband, 2002, Paper mill residuals and compost effects on soil carbon and physical properties, J Environ. Qual. 31: 2086-2095.

Gauthier, F. , Neufeld, J.D., Driscoll, B.T. , \& Archibald, F.S., 2000, Coliform Bacteria and Nitrogen Fixation in Pulp and Paper Mill Effluent Treatment Systems, Applied and Environmental Microbiology, Dec. 2000, p. 5155-5160.

Simard, R.R., R. Baziramakenga, S. Yelle. J. Coulombe., 1998, Effect of de-inking paper sludges on soil properties and crop yields. Can J Soil Sci. 78, 689-697.

Vallad, G. E., Cooperband L. and R.M. Goodmana., 2003, Plant foliar disease suppression mediated by composted forms of paper mill residuals exhibit molecular features of induced resistance, Physiol and Molec, Plant pathol 63: 65-77.

Widiastuti, H. Siswanto, Tri Panji, Suharyanto, Isroi, 2007, Pemanfaatan limbah sludge pabrik kertas untuk produksi pupuk bioorganik, jamur konsumsi dan enzim lignolitik secara simultan, Laporan Akhir Program Insentif KMNRT. 